\title{
生活環境評価のためのどこでも摩擦試験器
}

\section{Mobile friction tester for the evaluation of living environment}

\author{
○正 坂井伸朗（九工大）学 古澤 峷（九州大） 正 澤江義則 正 村上輝夫
}

Nobuo Sakai, Kyushu Institute of Technology, 1-1 Sensuicho, Tobata-ku, Kitakyushu

Tsukasa Furusawa, Kyushu University, 744 Motooka, Nishi-ku, Fukuoka

Yoshinori Sawae, Teruo Murakami

Keywords: Friction tester, Field measurement, Life space

\section{1.はじめに}

摩擦は表面同士がしゅう動寸るあらゆる場面に見られ る現象であり，ヒトの生活においても自明的に摩擦を利用 する場面が多く見られる。また，転倒を防止するために滑 止め材料を表面に付与したり, 滑り戸に潤滑作用を期待し た油脂成分を塗布するなど, 生活空間においても摩擦を制 御することは, より便利かつ安全安心な生活空間を構成す るための一つの重要な要素であると考えられる.特に公共 空間においては定量的かつ科学的な手法により環境が評 価され空間を設計することが望ましい，

ヒトの皮膚は各部位に関して合目的な摩擦特性を有す ると考えられる.特にヒト手掌は指紋・汗腺による表面テ クスチャや保湿制御挙動, 組織の粘弾性, 爪や骨の剛性要 素などの各特性が総合され高摩擦を実現していると考え られる。一方，顔皮膚といったその他の皮膚部位の摩擦は 美容製品の評価項目等として研究が進められている.この ような場面における摩擦測定では測定対象を摩擦試験器 に掛けるのが現実的ではないことが多い。

生活空間やそれらと相互作用するヒト皮膚あるいは生 活器具を摩擦という視点から臨床的に評価するためには, 試験器そのものを生活空間へ持出し, センサを対象物に対 してしゅう動させることで摩擦特性を得る必要がある. 本 研究では, どこでも摩擦試験というコンセプトの下, 生活 空間を摩擦の視点から定量的に評価するためのモバイル 型摩擦試験器を作製した.また使用例として生活空間を構 成すると考えられる各種の樹脂系材料の摩擦特性を測定 した.さらに，摩擦特性の現地調査の例として公共空間の 廊下といった床表面の摩擦特性について測定を行なった 結果を報告する。

\section{2. どこでも摩擦試験器の開発と測定方法}

本研究において必要となる摩擦試験器は測定対象に素 子をしゅう動させるペンタイプの試験器とした. Fig.1に 製作したモバイル摩擦試験器の写真を示す. 試験器は全長 $160 \mathrm{~mm}$ であり, 質量は約 $30 \mathrm{~g}$ である。試験器先端部位に 取付けられた 6 軸力覚センサ (BL AUTOTEC Inc., ThinNANO 5/4-A) により摩擦素子に加わる垂直力および 摩擦力を測定し, 力覚センサの先に取り付けられた摩擦素

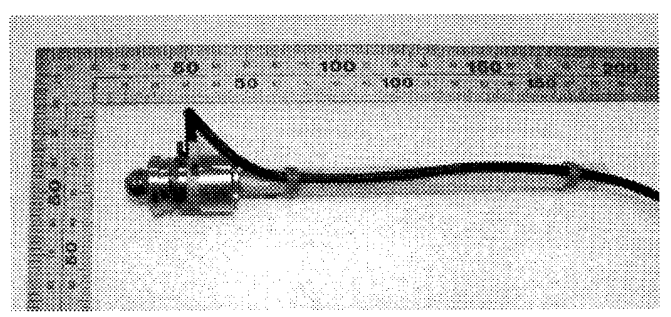

Fig. 1 A photograph of the mobile friction tester. In this report, friction attachment for rubbing surface was SUS440C sphere of $\mathrm{R}=5 \mathrm{~mm}$.
子は, 摩耗による損傷や使用目的に応じて取替え可能とし た. 本稿では試験的運用として R=5mm の SUS440C の 球を摩摖素子として用いた. センサ出力はセンサアンプに

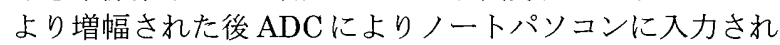
6 軸信号分離行列により各軸の力およびトルクを得た.

本装置のようにモバイルかつペン型の摩擦試験器を構 成した場合, 社会環境といった場面などどこでも摩擦測定 可能となる一方, ペン姿勢により重力の方向が変わり, そ の結果センサ值が変化する. 本稿では測定時の目標ペン姿 勢を試験前に定め, その状態を維持したままセンサ值のゼ 口点を取得し差し引くことで, 姿勢の影響を補償した。ま た, ヒトの手によりしゅう動させるため, 荷重制御が難し くなるが, 本研究では $1 \mathrm{~N}$ 荷重時の摩擦係数を代表值とし て採用し, 滑り速度は約 $30 \mathrm{~mm}$ と成るように測定者は事 前に訓練を行なった．滑り距離は約 $40 \mathrm{~mm}$ であり往復運 動とした. 状況に応じセンサ出力は $5 \mathrm{~Hz}$ をカットオフと する 2 次バターワース IIR(Infinite Inpulse Response)低 域通過デジタルフィルタによりノイズ除去を行なった。

\section{3. どこでも摩擦試験器による測定例}

各試験片はへプタンにより洗浄後測定を行なった。 Fig.2 にポリ塩化ビニルを測定した場合のデータを示す. ペン型でヒト手により荷重を加えているため荷重は正確 に $1 \mathrm{~N}$ を保つことはないが, 摩擦係数は適切な值を示した. 本摩擦試験器では極めて手軽に摩擦測定が可能である. そ こで, 代表的な 26 種類の樹脂系材料について摩擦係数を 測定した結果を Fig. 3 に示す. 13 アクリル樹脂は本稿で はキャスト材であり，24 ポリカーボネイトも表面粗さが 小さかったため摩擦係数が大きめであったと考えられる. ABS はゴム成分が存在し，ゴム成分の変形性による真実 接触面積の増加により摩擦係数が大きかったと考えられ る. 1 ナイロン, 4 PEEK, 19 PPS, 21 ポリアセタール は摩擦摩耗用グレードについても測定したが, 21 ポリア セタール以外は標準材と比較し摩擦係数は小さかった。 23 ポリカーボネイトの耐スクラッチ材(24 番)は表面に高 硬度シートが貼られていると見受けられ，その結果， 24 ポリカーボネイト耐スクラッチ材は摩擦係数が標準材と

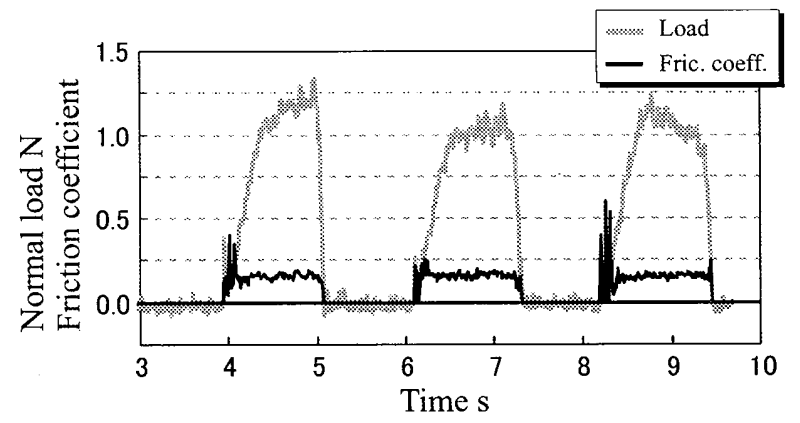

Fig. 2 A graph of experimental result in a mesurement of PVC plate. 


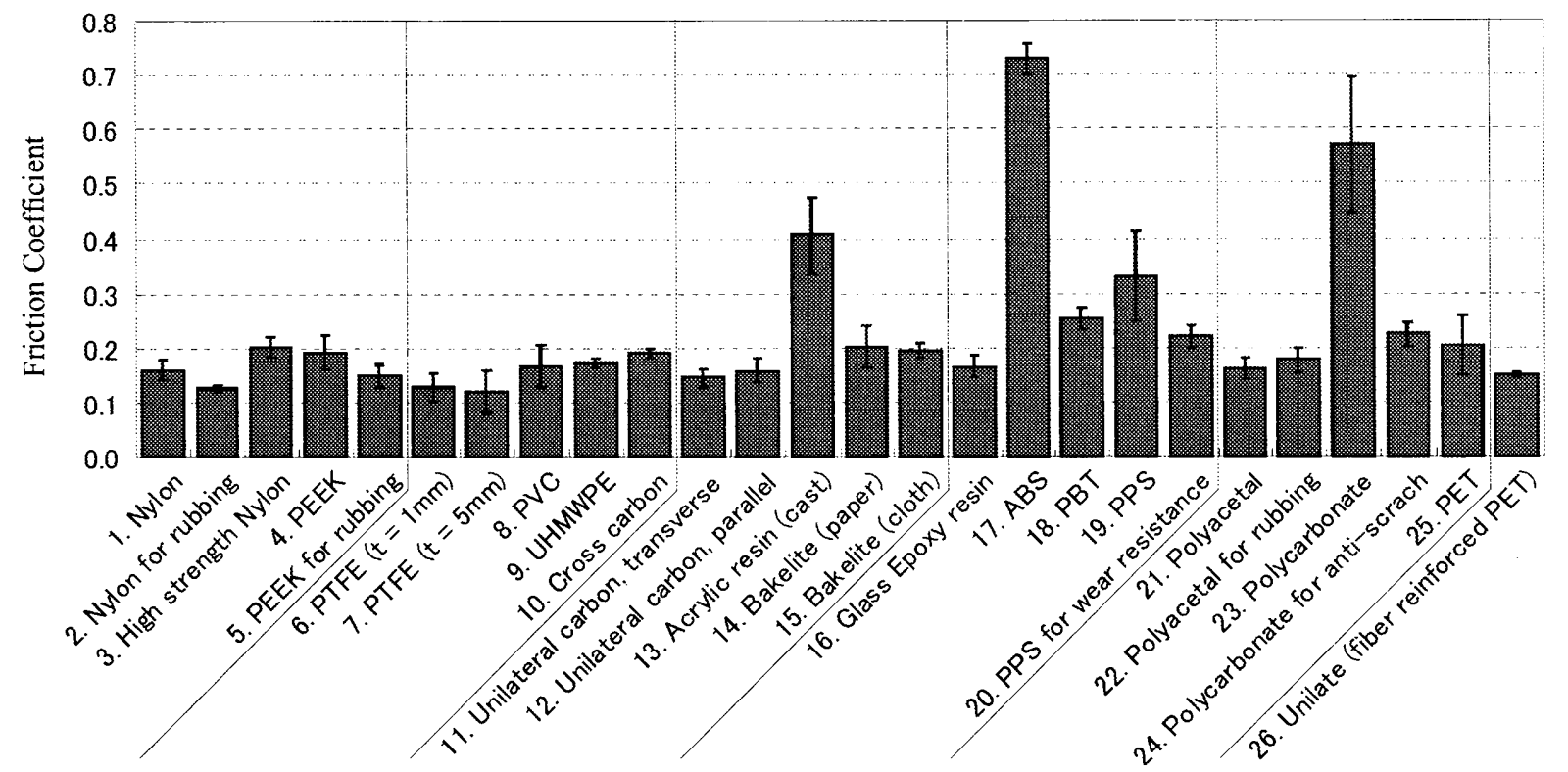

Fig. 3 Friction coefficient of various resin materials

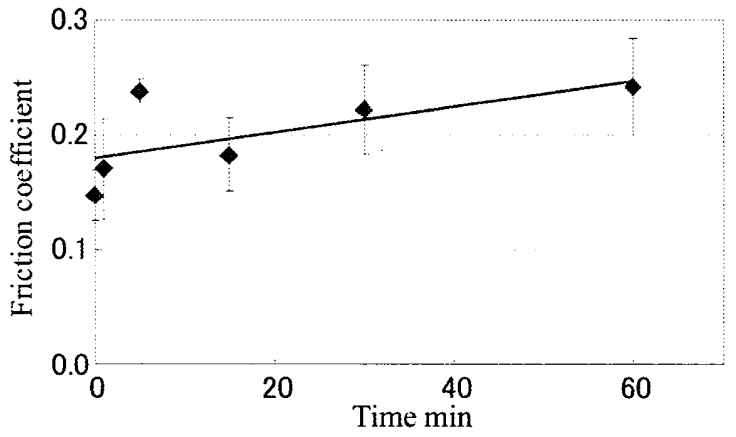

Fig. 4 Time-dependent behavior of PVC in a mesurement of friction coefficient.

比較し小さくなったものと考えられる.

PVC(ポリ塩化ビニル)など一部の材料については時間 経過による摩擦係数の変化が観察された. Fig.4 に PVC の摩擦係数の時間変化を示す. 本時間経過試験では, 測定 点以外の時間は摩擦させず室内放置し, 摩擦トラックは異 なる場所とした.PVC は時間経過により摩擦力が徐々に 増加した. またへプタン洗浄直後では摩擦係数が 0.05 程 度となる場合もあり， 30 秒程度で 0.1 を超える挙動を示 した. また, 手掌の脂成分やタンパク成分により容易に摩 擦係数が 0.1 を下回ることが確認された。

次に生活環境評価の例として大学内の廊下の摩擦係数 を測定した結果を示す，測定では初期面，台所洗剤による 拭取り，アルコールによる拭取り，ヘプタンによる拭取り の順で計測した. 初期状態では通常の人通りがある污れた 状態においても 0.35 程度の高摩擦が得られた. そこで中 性洗剂で拭取ると 0.46 程度に摩擦が大きくなった。 しか し, さらなる洗浄効果を得るためにエタノールやへプタン を用いると摩擦係数は 0.35 程度に低下した.

\section{4.考察およびまとめ}

本稿では各種樹脂系材料について摩擦係数測定を行な ったが一部の材料を除き摩擦係数は $0.13 \sim 0.24$ 程度であ った.しかし，これらの結果はへプタン洗浄状態であり， 表面の污れの状態により大きく摩擦係数が変化する様子 が見られたことから, 生活環境では表面状態が摩擦係数に

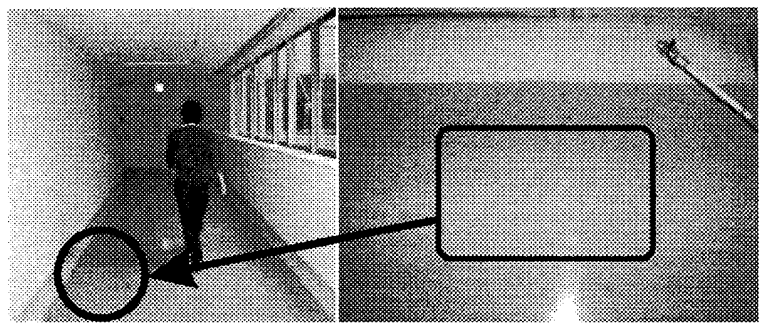

Fig. 5 Photograph of the place where field test was held in a passageway in Kyushu University.

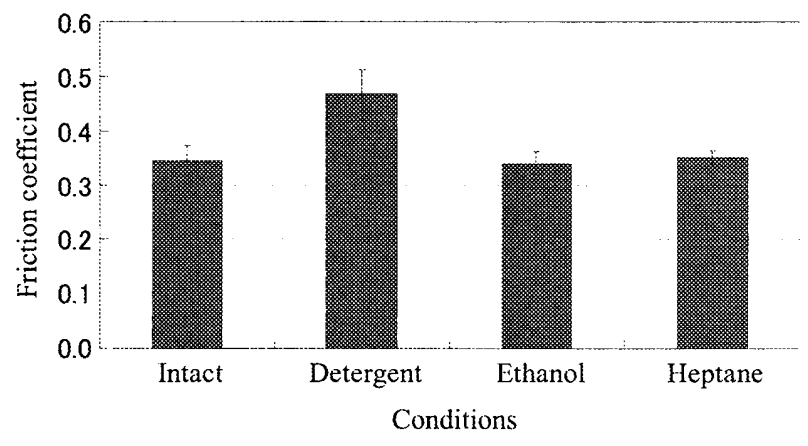

Fig. 6 Change of friction coefficient in each condition.

大きく影響を与えることが予測された．

一方, 生活環境測定例として行なった廊下の摩擦係数で はワックスによる表面コートが施されている面で行なっ た.これらのワックスにはポリマーやタンパク成分により 高機能化されていると考えられ, エタノールやへプタンは それらの成分を変性させてしまう可能性がある.また，床 面惊摩擦であれば良いというわけではないと考えられ， 床面の基材であるゴム材料による掘起し項と併せ, 摩擦係 数が変化しやすい公共の環境という悪条件の中にありな がら, 適切な摩擦係数が維持されていることが推測された。 今後, 濡れた面やゴム系材料など様々な条件を测定すると 共に,フィールドを街など広範囲において測定を行なう計 画である。

【謝辞】本研究は一部, 科学研究費補助金挑戦的萌芽研究 （21650151）の支援を得た。 